\title{
The Gender Gap In Malaysian Public UNIVERSITIES: EXAMINING THE 'LOST BOYs'
}

\author{
Jonathan Yong Tienxhi ${ }^{\mathrm{a}}$ \\ Penang Institute
}

\begin{abstract}
This paper examines the growing gender gap between men and women in Malaysian public universities, using the Gender Parity Index (GPI) to measure gender disparities over time. It considers the gender gap in University of Malaya with other prominent overseas universities, and compares the GPI between all twenty public higher education institutions for the years 2009-2013. It also compares the GPI of public universities in Malaysia with local private education institutions, and examines the gender disparities in public universities in terms of subject segregation. Particular attention is paid to the gender segregation in terms of Science, Technology, Engineering and Mathematics (STEM) subjects; gender segregation in STEM subjects in Malaysian public universities is compared to East Asia Pacific averages. Lastly, various causes and explanations for the gender gap are explored.
\end{abstract}

Keywords: gender, higher education, disparity, STEM

\section{Introduction}

Men have dominated the global higher education landscape for most of recorded history; in the UK, women were not allowed to enrol into universities until 1920. However, enrolment trends since the 1990s have produced a reverse gender gap globally, with women outnumbering men in almost all Organisation for Economic Co-operation and Development (OECD) countries (Vincent-Lancrin, 2008). This disparity between men and women in terms of access to higher education has been a worldwide phenomenon with women comprising the majority of tertiary students in 93 out of 146 countries examined by the Atlas Gender Equality report (UNESCO, 2012). It is important to note that due to demographic trends, the majority of students live in countries in which men still outnumber women in higher education (54\% of youth), particularly in sub-Saharan Africa. Nevertheless, the development of reverse gender gap has caused researchers on education to orient their attention to the unique problems faced by males in the education system, in what was called 'The Boy Turn' (Weaver-Hightower, 2003). The reverse gender gap has received greater scrutiny by researchers and policy makers over the past several years, as the problem of the falling rate of male enrolment is increasingly acknowledged. The Higher Education Policy Institute (HEPI), a think tank based in the UK, has referred to the phenomenon as a 'national scandal' (Weale, 2016), while the Malaysia Education Blueprint 2013-25 specifically mentioned the problem of 'lost boys', warning that these alienated youths are a potential source of social instability (Ministry of Education Malaysia, 2012).

Why is this issue worth paying attention to? Some might argue that whatever disparities faced by men in the sphere of education, this hardly translates into an enduring disadvantage. After all, women continue to be left behind in Malaysia's political and economic spheres. In 2015, Malaysia was ranked 111 out of 146 nations surveyed by the World Economic Forum in terms of the gender gap, the worst placed nation in the Association of South East Asian Nations (ASEAN) region (World Economic Forum, 2015). This paper disagrees with the premise that male disparity in higher education enrolment is not worth paying attention to due to the prevalence of structural disadvantages against

\footnotetext{
Correspondence can be directed to: j.yong-tienxhi@lse.ac.uk
} 
women. Firstly, it implies that the problem of under-enrolment of men in universities can only be resolved if resources and effort are taken away from helping women achieve equity in other spheres of life. In fact, disparity for or against one gender does not automatically result in an adverse impact on the other. As Nick Hillman, HEPI director noted, 'policymaking is not a zero-sum game in which you have to choose between caring for one group or the other' (Weale, 2016). Rather, we ought to understand and eradicate differences in opportunity where we can find them. Secondly, the gap between men and women in higher education hurts those at disadvantage the most, hence increasing overall social inequality. Young men from poor income families are disproportionately affected by the gender gap in universities, and the Universities Colleges and Admissions Service (UCAS) has pointed out 'the widening gap between men and women is acting to stall progress in reducing inequality overall' (UCAS 2015, p.1). As we will observe in this paper, the gender gap in Malaysian public universities is significantly wider compared to Malaysian private universities. As public university tuition is vastly lower than private university, this indicates that the gender gap has a much greater effect on men from lower income groups. Hence, closing the higher education gender gap could have a positive effect on social equality as a whole.

Given the importance of studying the higher education gender gap, this paper hopes to examine the extent in which Malaysian public universities have been part of this global trend, and to understand the specifics of how the reverse gender gap has emerged in particular Malaysian universities and fields of study. In addition to this, this paper will consider various explanations for the emergence of this gender gap, in order to explain the disappearance of these 'lost boys'.

\section{The Gender Parity Index}

The tool used in this paper to capture the changing demographics of university enrolment is a measure known as the Global Parity Index (GPI), which can be found by dividing the number of females over the number of males in a certain student population and rounding up to two decimals. A GPI of less than 1 represents a disparity in favour of males, while a GPI above 1 represents a disparity in favour of females. The GPI is commonly used in reports by international organisations, such as in the UNICEF report 'Why are Boys underperforming in Education?' and the 2012 World Atlas of Gender Equality in Education produced by UNESCO's Institute of Statistics. According to UNESCO (2012), a GPI measurement of 0.97-1.03 indicates that gender parity has been achieved.

\section{The Gender Gap and National Wealth}

The countries in which women in higher education are still disadvantaged tend to be those with low Gross Domestic Product (GDP) per capita, such as sub-Saharan African nations. Conversely, nations with high GDP per capita tend to have a higher level of GPI. This is according to the World Atlas of Gender Equality in Education 2012, which shows that there is a strong correlation between rising GPI in tertiary education and a country's national wealth (UNESCO 2012, p.80). For example, nations which have high national wealth tend to have higher GPI such Iceland and Norway, with GPI of at least 1.4. Prime Minister Najib Razak has recently stated that Malaysia is on track to be a high income nation by 2020 (Goh, 2015). Even if this timeline is exaggerated, this raises the possibility that as Malaysia increases its national income, there will be corresponding rise in GPI. It should be noted that there are many exceptions to the general trend between GPI and national wealth. Japan has a GPI lower than 1 despite being a high income nation, while the Philippines has a relatively high GPI despite having less GDP per capita than Malaysia. Of course, Malaysia's progress into a high income nation should be welcomed, and it is not predetermined that there will be an increase in the higher education gender gap. However, the global trends suggest a need to anticipate this problem by paying closer attention to male under-enrolment where it is strongest. In the context of Malaysia, this is in our public universities. 


\section{The Gender Gap Reversal in Malaysian Public Universities}

The gender gap in Malaysian public universities is comparable to the international trends outlined earlier, with the gap beginning to emerge towards the end of 1990 s and rising quickly in recent years. According to Malaysia's Gender Gap Index report, the combined gross enrolment ratio was in favour of men in 1980 (53\%-56.9\%), but parity was achieved by 1990; women have had a higher enrolment ratio since 2000, of 65.3\%-64.3\% (Ministry of Women, Family and Community Development Malaysia, 2007). This disparity was already notable by the turn of the century, as former premier Mahathir Mohamed once asked 'Where have the bumiputera (translated as 'sons of the soil', to refer to the Malay race and other indigenous groups in Sarawak and Sabah) male students gone to? Are they not interested in education? Or are their qualifications (to enter university) too low?' (Khoo 2003, p.197). Despite this, a detailed examination of the gender gap in Malaysian higher education has not been made. Instead, the academic literature on educational inequality in Malaysia has tended to focus on the ethnic divide rather than gender disparity. This was seen in recently published books such as The Colour of Inequality and The Emergence and Widening of the Ethnic Divide in the Malaysian Educational System. This is partly due to the tremendously important political and social dynamics of ethnicity within the education system, but also due to the perception that gender inequity is no longer a pressing matter with regards to education. In 1999, it was found that 'the gender gap in attaining upper secondary school within an ethnic group is relatively small compared to the ethnic gap' in Malaysia (Pong 1999, p.165). By the 1980s, it was found that increasing levels of education attainment were 'evenly distributed among genders' (Milanovic, 2006). This may have been true around the turn of the century, but does not take into account data which indicate that educational disparity according to gender has begun to increasingly widen in recent years, this time to the detriment of men.

\section{The Gender Gap at the University of Malaya and National University of Singapore}

As Malaysia's oldest and most prestigious institution of higher education, the University of Malaya (UM) has been emblematic of the shift from female underrepresentation to forming the majority of undergraduates. Two years after independence, UM enrolled 77 female undergraduates, comprising a mere $10.7 \%$ of their total undergraduate student population (Ministry of Women and Family Development, 2013), while the female undergraduate enrolment in 2012 was $61.6 \%$. The drastic change in gender ratio has changed the discourse of educational inequity from enabling educational access to female students to ensuring equitable participation of males in education.

UM was established in 1949 under the Carr-Saunders Commission, and the University of Malaya in Kuala Lumpur was formed in 1962 (refer to University of Malaya, n.d.). During the first six years of UM in Kuala Lumpur, GPI remained more or less stagnant, as male student enrolment increased at an even faster rate than female student enrolment (Ministry of Education Malaysia, 1967). This is in stark contrast to the current gender enrolment ratio at UM. In 2013, the GPI for undergraduates at UM was 1.63, a disparity which is greatly in favour of women. The percentage of women enrolled in undergraduate programmes at UM increased from 24.5\% in 1962, to 62\% in 2013 (Ministry of Education Malaysia, 2013). These numbers show the extent to which women have succeeded in drastically increasing their participation in the premier higher education institution of the country.

Comparing the gender parity of UM with National University of Singapore (NUS) is revealing, as the two share historical roots and geographical proximity. Since NUS is located in Singapore, a country with a higher national income than Malaysia, this makes the gender disparity in Malaysia even more notable. When comparing undergraduate data between the two universities, we find that the gender disparity in UM is consistently higher compared to NUS between the years 20092013. The GPI of UM for this period ranges between 1.58-1.6 (Ministry of Education Malaysia, 2013; Ministry of Higher Education, 2010; 2011; 2012) while the GPI of NUS ranges between 1-1.04 (NUS Registrar's Office, 2016). The GPI of NUS can be considered to be achieving gender parity, as it is very close to the range of $0.97-1.03$, which is considered by UNESCO to be the range of gender parity. This 
trend shows that despite sharing a common history and relatively close geographical and cultural similarities, the gender parity within UM is unusually high. However, there are twenty other public universities currently operating in Malaysia. Is the gender gap at UM an anomaly within Malaysian higher education or is it a representative of a larger phenomenon?

\section{GPI Comparison of Malaysian Public Universities}

There are twenty public universities (IPTAs) currently operating in Malaysia. It should be noted that UNICEF categorises any country with a GPI less than 0.8 or higher than 1.25 to be 'far from goal' of gender parity (World Bank, 2004). As all but four Malaysian IPTAs would fall into that category, we have used a more lenient classification to avoid polarising the data. UNICEF's definition of gender parity at 0.97-1.03 is maintained, but we include categories 'close to parity', 'intermediate disparity', while classifying extreme disparity at GPI less than 0.5 or over 1.5 . We also highlight the universities which have disparities that go well beyond 1.5 in order to illustrate the depth of the problem.

Table 1. GPI of Enrolment Ratio for all Malaysian IPTAs in 2013

\begin{tabular}{|c|c|c|c|c|c|c|c|}
\hline \multicolumn{3}{|c|}{ Fewer women enrolled } & \multirow{3}{*}{$\begin{array}{l}\text { Gender } \\
\text { Parity } \\
\text { Parity } \\
(0.97- \\
1.03)\end{array}$} & \multicolumn{4}{|c|}{ Fewer men enrolled } \\
\hline \multirow{2}{*}{$\begin{array}{l}\text { Extreme } \\
\text { disparity } \\
(<0.5)\end{array}$} & \multirow{2}{*}{$\begin{array}{l}\text { Intermediate } \\
\text { disparity } \\
(0.5-0.89)\end{array}$} & \multirow{2}{*}{$\begin{array}{l}\text { Close } \\
\text { to } \\
\text { Parity } \\
(0.9- \\
0.96)\end{array}$} & & \multirow{2}{*}{$\begin{array}{l}\text { Close to } \\
\text { Parity } \\
(1.03-1.1)\end{array}$} & \multirow{2}{*}{$\begin{array}{l}\text { Intermediate } \\
\text { disparity } \\
(1.11-1.5)\end{array}$} & \multicolumn{2}{|c|}{ Extreme disparity } \\
\hline & & & & & & (>1.5-1.99) & $(>2.0)$ \\
\hline $\begin{array}{l}\text { Universiti } \\
\text { Pertahanan } \\
\text { Nasional } \\
\text { Malaysia } \\
\text { (UPNM) }\end{array}$ & $\begin{array}{l}\text { Universiti } \\
\text { Teknologi } \\
\text { Malaysia } \\
\text { (UTM), } \\
\text { Universiti } \\
\text { Teknikal } \\
\text { Malaysia } \\
\text { (UTEM) }\end{array}$ & & $\begin{array}{l}\text { Universiti } \\
\text { Tun } \\
\text { Hussein } \\
\text { Onn } \\
\text { Malaysia } \\
\text { (UTHM), } \\
\text { Universiti } \\
\text { Malaysia } \\
\text { Perlis } \\
\text { (UniMAP) }\end{array}$ & $\begin{array}{l}\text { Universiti } \\
\text { Malaysia } \\
\text { Pahang } \\
\text { (UMP) }\end{array}$ & $\begin{array}{l}\text { Universiti } \\
\text { Islam } \\
\text { Antarabangsa } \\
\text { Malaysia } \\
\text { (UIAM) }\end{array}$ & $\begin{array}{l}\text { Universiti } \\
\text { Malaya } \\
\text { (UM), } \\
\text { Universiti } \\
\text { Sains } \\
\text { Malaysia } \\
\text { (USM), } \\
\text { Universiti } \\
\text { Utara } \\
\text { Malaysia } \\
\text { (UUM), } \\
\text { Universiti } \\
\text { Malaysia } \\
\text { Sabah } \\
\text { (UMS), } \\
\text { UniversitiKe } \\
\text { bangsaan } \\
\text { Malaysia } \\
\text { (UKM) }\end{array}$ & $\begin{array}{l}\text { Universiti } \\
\text { Putra } \\
\text { Malaysia } \\
\text { (UPM), } \\
\text { Universiti } \\
\text { Malaysia } \\
\text { Sarawak } \\
\text { (UniMAS), } \\
\text { Universiti } \\
\text { Pendidikan } \\
\text { Sultan } \\
\text { Idris(UPSI), } \\
\text { Universiti } \\
\text { Teknologi } \\
\text { Mara (UITM), } \\
\text { (Universiti } \\
\text { Sultan Zainal } \\
\text { Abidin } \\
\text { (UniSZA), } \\
\text { Universiti } \\
\text { Malaysia } \\
\text { Terengganu } \\
\text { (UMT), } \\
\text { (Universiti } \\
\text { Sains Islam } \\
\text { Malaysia } \\
\text { (USIM), } \\
\text { (Universiti } \\
\text { Malaysia } \\
\text { Kelantan } \\
\text { (UMK) }\end{array}$ \\
\hline
\end{tabular}


Table 1 above demonstrates that UM's GPI of 1.63 is far from an anomaly, but falls well within Malaysian norms. While 1.63 does represent extreme disparity, most Malaysian IPTAs fall within this classification (13 out of 20 universities). In fact, 8 public universities have a GPI of over 2.0, which indicates that female undergraduates more than double their male counterparts in those universities. Only two universities can be said to have achieved gender parity, while one university has extreme disparity against women. The three universities which show disparity against women are UPNM, UTM, and UTEM. These disparities can be explained by the course of studies and faculties available or emphasised at these universities. As we will see in the section below on subject gender segregation, engineering remains the sole course of study which still harbours a significant disparity against women, with a GPI of 0.58. UTM is among the top 100 universities in the world for engineering and technology according to the QS world rankings, and offers no less than 22 bachelor degrees in the field of engineering; while in UTEM, five out of seven of their faculties are for engineering. The only IPTA with extreme gender disparity against women is the National Defence University of Malaysia (UPMN), with a GPI of 0.41 (30\% female). This is undoubtedly due to the subject orientation at the university (National Defence), which reflects that military remains a male dominated field.

This table shows that gender inequality has become a significant phenomenon in certain sectors of the Malaysian higher education landscape. Inequity against women persists in certain subjects and fields, particularly national defence and engineering. But on a broader scale, men in public universities have become increasingly underrepresented. By tracing the GPI of Malaysian public universities over a period of five years, we can see the trend of increasing gender disparity over time.

\section{Table 2. Comparison of Malaysian IPTA's GPI, 2009 to 2013}

\begin{tabular}{|l|l|l|l|l|l|}
\hline Comparison of Malaysian Public Universities GPI (Undergraduate) \\
\hline University/Year & 2009 & 2010 & 2011 & 2012 & 2013 \\
\hline UM & 1.58 & 1.6 & 1.56 & 1.6 & 1.63 \\
\hline USM & 1.57 & 1.58 & 1.59 & 1.65 & 1.67 \\
\hline UKM & 2 & 2.11 & 1.99 & 2.13 & 1.94 \\
\hline UPM & 2.2 & 2.2 & 2.11 & 2.17 & 2.18 \\
\hline UTM & 0.85 & 0.83 & 0.8 & 0.77 & 0.81 \\
\hline UUM & 2.3 & 2.06 & 2 & 1.98 & 1.91 \\
\hline UIAM & 1.68 & 1.57 & 1.53 & 1.5 & 1.48 \\
\hline UniMAS & 1.85 & 2.01 & 2.15 & 2.1 & 2.1 \\
\hline UMS & 1.66 & 1.86 & 1.91 & 1.91 & 1.76 \\
\hline UPSI & 2.49 & 2.59 & 2.66 & 2.94 & 2.89 \\
\hline UITM & 1.91 & 1.93 & 1.91 & 2 & 2.01 \\
\hline UniSZA & 2.96 & 2.79 & 2.76 & 2.65 & 2.68 \\
\hline UMT & 2.29 & 2.3 & 2.42 & 2.52 & 2.68 \\
\hline USIM & 2.84 & 2.76 & 2.44 & 2.58 & 2.57 \\
\hline UTHM & 0.93 & 0.87 & 0.88 & 0.98 & 1.03 \\
\hline UTEM & 0.64 & 0.71 & 0.77 & 0.74 & 0.75 \\
\hline UMP & 0.85 & 0.97 & 1.07 & 1.09 & 1.1 \\
\hline UniMAP & 0.8 & 0.83 & 0.91 & 0.92 & 0.98 \\
\hline UMK & 1.85 & 1.93 & 2.18 & 2.34 & 2.61 \\
\hline UPNM & 0.17 & 0.26 & 0.33 & 0.41 & 0.4 \\
\hline All Universties & 1.66 & 1.65 & 1.66 & 1.7 & 1.71 \\
\hline SOUn: & & 2.96 & & \\
\hline
\end{tabular}

Sources: Ministry of Higher Education Malaysia (2011; 2012) and Ministry of Education Malaysia (2013) 
Table 2 above tracks the GPI ratio for all 20 IPTAs from the year 2009-2013.The data reveals that overall gender disparity has worsened across these years, as the GPI has shifted from 1.66 to 1.71 in the space of five years. While UM shows an increase in disparity across this period (from 1.581.63), this is actually below the national average of 1.71 . This trend will undoubtedly be amplified if we use data going further back in history, or over a longer period. The gender parity in Malaysian IPTAs is high even by international standards- $55 \%$ of undergraduates in the UK were female in 2011, while women consisted of $56.4 \%$ of public university students in the U.S in 2010 (Borzelleca, 2012). At the same period, female undergraduate enrolment in Malaysian IPTAs was at $62 \%$ and rising.

While there remain a few universities which possess disparities against women, there are reasons to be optimistic about this problem based on the trends of the data shown. Only two universities (UPNM and UTEM) possess a GPI in favour of men which UNICEF would consider 'far from goal' of gender parity (less than 0.8 ) as of 2013. Both universities show a trend of improving gender parity from 2009-13, with UTEM going from 0.64-0.75, while UPNM gender parity increased from $0.17-0.4$. The same cannot be said of the universities at the other end of the spectrum, as 8 out of the 13 universities classified as having extreme disparity in favour of women worsened in terms of GPI during this period, such as UPSI (2.49 to 2.89) and UMK (1.85-2.61). This indicates that the underrepresentation of men in Malaysian public universities will continue to be an underlying problem for the foreseeable future, and could plausibly worsen over the coming years.

Figure 1. Male and female enrolment trends at IPTAs 2009-13

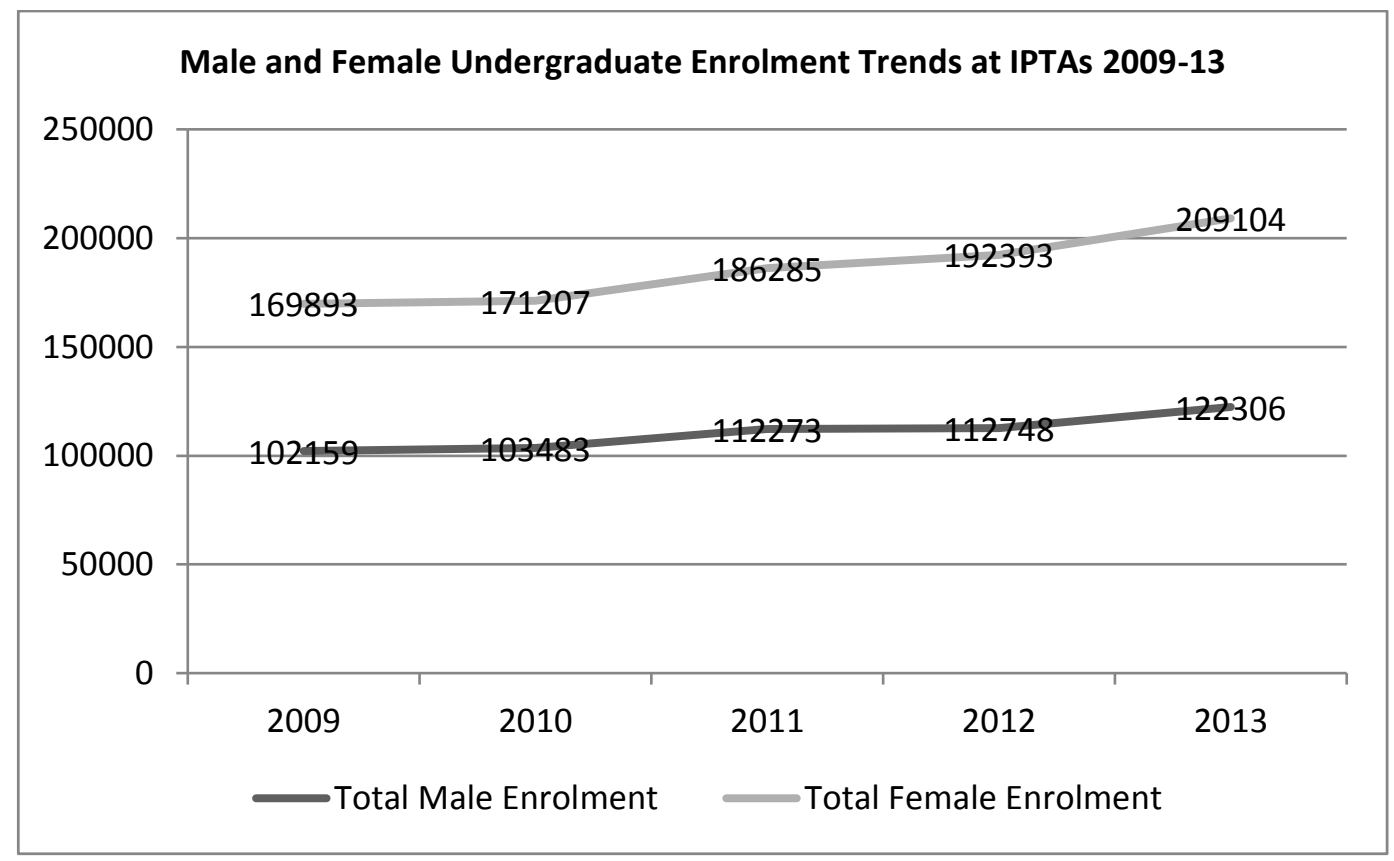

Sources: Ministry of Higher Education Malaysia (2011; 2012) and Ministry of Education Malaysia (2013)

The gender gap in Malaysian IPTAs is substantial and worthy of further study. Figure 1 shows the difference between male and female enrolments in the year 2013 amounted to 86,798 students, a figure which is itself equal to $26 \%$ of Malaysia's entire undergraduate student population in public universities. Furthermore, the numerical gap between male and female enrolments has been steadily increasing from 2009-2013. In 2009, the gap between male and female students was 67,734 students. 
In 2011 , this had increased to 74,012 students, before culminating to a gap of 86,798 students in 2013. This shows a worrying trend of expanding gender disparities in public universities. One positive trend which can be discerned is that while the gender gap is widening, male enrolments overall are still increasing, albeit at a much slower pace. If male enrolments begin to stagnate or decline, these trends will be greatly exacerbated.

\section{Comparing the Gender Gap of Public Universities in Malaysia with the Private Sector}

This section focuses on the gender gap within Malaysian public universities, but it may be instructive to consider how this gender parity compares to Malaysian private universities (IPTS). As of March 2015, 509 active IPTS campuses are operating in Malaysia. These include universities (61), colleges (405), university colleges (34) as well as branch campuses of foreign universities (9) (Ministry of Higher Education Malaysia, 2012). With regards to total student enrolment in 2013, IPTS institutions in Malaysia have a slight disparity in favour of women, with a GPI of 1.06; much closer to attaining gender parity compared to total student enrolment in IPTA institutions which have an average GPI of 1.57 (Ministry of Higher Education, 2012). Focusing on undergraduate students further widens the difference in GPI, as IPTA universities have a GPI of 1.7 as compared to the IPTS institutions, which attain gender parity at 0.98 . The numbers show that the gender gap in Malaysian higher education mainly pertains to public universities.

Of course, an overall GPI which is close to parity may obscure inequities within particular institutions, particularly as there are over 500 IPTS campuses within Malaysia. Among some of the more prominent IPTS universities, there exists a wide spectrum of gender disparities. For example, Limkokwing and Nottingham Universities had intermediate disparity against women, with GPI between 0.5 and 0.89 (Ministry of Higher Education Malaysia, 2012). Meanwhile, Sunway University and HELP University had intermediate disparity in favour of women, with GPI between 1.11 and 1.5 (Ministry of Higher Education Malaysia, 2012). It should be noted that none of the institutions I examined had extreme disparities in favour of men or women, and all had GPI below the average of IPTA universities. This is in stark contrast to the GPI of public universities, where over half had GPI that could be considered extreme disparity. This affirms the notion that the gender gap between men and women is particularly large in Malaysian public universities as compared to the private sector.

It is not immediately clear why IPTS universities have far less of a gender gap compared to IPTA universities in Malaysia. The evidence for the relationship between private institutions of education and gender parity is mixed and often contradictory. In countries in which women form a minority of tertiary student population, private universities can often be more equitable in terms of gender parity, such as the case of Kenya where women consist of $54 \%$ of private university students compared to $32 \%$ of public university students (Onsongo, 2011). However, in the U.S, it has been argued that private universities discriminate against women in order to maintain gender balance; while public universities are more meritocratic in terms of admissions (Birger, 2015). One plausible explanation for disparity in Malaysia is that the boys and men who are left behind due to the gender gap consist primarily of those from lower income families, and thus has a stronger impact on IPTA universities which are far cheaper in comparison to IPTS universities.

\section{The Gender Gap by Subject Segregation}

The gender gap in Malaysian higher education needs to be understood in the context of gender segregation by subject in universities. This refers to the phenomenon in which male and female students tend to enrol in different faculties and courses at university; hence an overall increased female participation rate does not automatically lead an increase in gender parity across different faculties. This segregation has been said to account for between $15 \%$ to $25 \%$ of the gender income gap among college students (Bobbitt-Zeher, 2007). 
The segregation of gender in Malaysian higher education needs to be considered in order to understand the gender gap. In which fields of study, if any, has gender parity been attained? And how does this compare to global norms? These are the questions we consider in the following section:

Figure 3. GPI according to field of study in Malaysian IPTAs 2010-13

\begin{tabular}{|l|c|c|c|c|c|}
\hline \multicolumn{2}{|l|}{ Field of Study/ Year } & 2010 & 2011 & 2012 & 2013 \\
\hline Education & GPI & 2.26 & 2.33 & 2.66 & 2.37 \\
\hline Arts \& Humanities & GPI & 1.7 & 1.7 & 1.69 & 1.65 \\
\hline Social Science, Business \& Law & GPI & 2.05 & 2.03 & 2.07 & 2.04 \\
\hline Science, Mathematics \& Computers & GPI & 1.63 & 1.62 & 1.66 & 1.69 \\
\hline Engineering, Manufacturing \& Construction & GPI & 0.72 & 0.73 & 0.73 & 0.75 \\
\hline Agriculture \&Veterinary & GPI & 1.44 & 1.26 & 1.27 & 1.3 \\
\hline Health \& Welfare & GPI & 2.33 & 2.36 & 2.52 & 2.51 \\
\hline Services & GPI & 1.46 & 1.54 & 1.58 & 1.53 \\
\hline
\end{tabular}

Source: Ministry of Education Malaysia (2013)

Table 3 shows the enrolment in the eight major fields of study in Malaysia according to gender for the years 2010-2013. We find that women outnumber men in seven out of the eight fields of study, including areas in which women are traditionally underrepresented such as mathematics and science. This is shown by the GPI which is consistently higher than 1.0 with the exception of one field of study. The only field of study in which men continue to outnumber women is in engineering, manufacturing and construction. How does this compare to international norms? Women in Malaysian public universities have higher representation in each field on study in comparison to other countries within the East Asia and Pacific region (UNICEF 2009, p.32). While the regional average for female representation in social sciences, business and law is slightly less than $50 \%$, women comprise $67 \%$ of students in the same field of study. In fields of study where women consists of a majority, such as health and welfare (about 64\%), the trend is even more pronounced in Malaysian public universities (71\%). While women in the same region are underrepresented in the fields of science and mathematics, women in Malaysia make up $62.8 \%$ of the student population in those fields. Finally, even in the field of engineering, manufacturing and construction where women in Malaysia are still a minority, they come much closer to gender parity compared to the regional average, which is less than $20 \%$ compared to $43.1 \%$ in Malaysia (UNICEF, 2009).

These figures are noteworthy because degrees in STEM fields have often been an exception to the global trend towards increasing women enrolment in universities. A recent report from the National Student Clearinghouse looks at degrees in STEM fields and finds that the share of STEM bachelor's degrees going to women in the U.S has actually decreased over the past decade (National Student Clearinghouse, 2015). While overall parity in undergraduate enrolment has increased worldwide, this has not been the case in STEM disciplines where there are more male than female students in 91\% of countries examined (UNESCO 2015, p.3). Furthermore, the OECD (2011) found that STEM fields have become increasingly unpopular for women as they progress in their academic fields, with declining rates of women opting to study past a Bachelors' degree to Masters and then PhDs. A closer examination of the degree choices within those fields of study can reflect the extent to which Malaysian public universities differ from these trends. 
Table 4. GPI and Percentage of Women in STEM Subjects (Public Universities)

\begin{tabular}{|l|l|c|c|c|c|c|}
\hline Degree & & Men & Women & All & GPI & \% of which are women \\
\hline Engineering & Bachelors & 42309 & 34615 & 76924 & 0.82 & 45 \\
\hline & Masters & 6543 & 6377 & 12920 & 0.97 & 49 \\
\hline & Doctorate & 4380 & 2607 & 6987 & 0.6 & 37 \\
\hline Mathematics & Bachelors & 1512 & 4450 & 5962 & 2.94 & 75 \\
\hline & Masters & 264 & 709 & 973 & 2.69 & 73 \\
\hline & Doctorate & 313 & 369 & 682 & 1.18 & 54 \\
\hline & Bachelors & 3286 & 8275 & 11561 & 2.52 & 72 \\
\hline & Masters & 3909 & 7121 & 11030 & 1.82 & 65 \\
\hline Technology & Doctorate & 2102 & 2506 & 4608 & 1.19 & 54 \\
\hline & Bachelors & 2581 & 4098 & 6679 & 1.59 & 61 \\
\hline & Masters & 534 & 540 & 1074 & 1.01 & 50 \\
\hline & Doctorate & 333 & 180 & 513 & 0.54 & 35 \\
\hline
\end{tabular}

Source: Malaysian Higher Education Statistics, 2013

Table 4 above shows that in the traditional STEM fields, women have overtaken men in every degree with the exception of engineering. In the fields of science and mathematics, this true at every level of academic qualification from bachelor degree to doctorate. With regards to engineering, Malaysia has attained an impressive degree of gender parity, with women comprising of $45 \%$ of undergraduates. This is indeed surprising considering that global underrepresentation of women in engineering courses. For an instance, female engineering undergraduates in the US comprise a mere $17 \%$ of the student population according to the National Student Clearinghouse (2015). In Canada, the University of Toronto recently celebrated the fact that their engineering courses had $30 \%$ female enrolment, higher than any other university in Ontario (Engineering Strategic Communications, 2015). Closer to home, $19.5 \%$ of engineering undergraduates in the Republic of Korea were female in 2011 (UNESCO 2015, p.4). A more detailed breakdown of the degree choices would be required to examine whether or not further inequities exist within these subject choices.

Malaysia's achievements in attaining gender parity for women in STEM fields are worthy of emulation, and serves as a convincing counterpoint to former Harvard President Lawrence H. Summers' comments that the underrepresentation of women in science fields at universities may be due to innate differences (Hemel, 2005). In a paper entitled 'Why is Computer Science in Malaysia Dominated by Women?', it is argued that 'The fact that in Malaysia, women's education, and their positions in computer science departments and software employment being equivalent to those of men, undoubtedly contributes to such relative optimism about gender and technology relations in developing countries', showing that women are able to compete equally when they are not faced with cultural and institutional stereotyping (Mellstrom 2009, p.887) The question that arises in the Malaysian context is whether or not men have been at the receiving end of some of these negative stereotypes and institutional barriers, particularly when they comprise a mere $25 \%$ of undergraduates in mathematics. In the same paper, one female computer science professor expressed the view that the boys in her department 'don't seem motivated enough and we also have problems with young men dropping out of class.' (Mellstrom 2009, p.897) We will consider these and other explanations for the gender gap below. 


\section{Causes of the Gender Gap}

The causes of the gender gap in Malaysian public universities undoubtedly involve a complex array of factors. The first possible cause we will consider is that men are underrepresented in public universities because they pursue alternative tertiary pathways, including polytechnics, community colleges and overseas universities. We also consider the other explanations typically ascribed to explain the higher education gender gap, and examine them in the Malaysian context. This would include higher returns to education for women, better performance in secondary schooling, and negative socialisation of men.

The difference between the number of men and women enrolled in undergraduate IPTA programmes in 2013 was 86,798 students. Given that there are marginally more men than women in the Malaysian population ( $\mathrm{ClA}, 2016)$, this suggests that there could be potentially over 86 thousand more men in Malaysian public universities. Where have these missing men gone to? We have already seen that men are overall marginally better represented in IPTS universities, thus it is clear that the absence of male students in IPTA universities cannot be explained by their proliferation in the private sector of higher education. This section considers the possibility that male youth have entered alternative pathways to higher education, and thus are underrepresented in Malaysian public universities. One possibility is that men have chosen alternative routes for career advancement by enrolling into polytechnics \& community colleges. A second possibility is that male students are sufficiently privileged to enter higher quality institutions than IPTAs, and are sent to overseas universities. Both of these possibilities will be examined to identify the extent to which they can explain the gender gap.

\section{Men at Polytechnics and Community Colleges}

From 2009-2013, male enrolment in polytechnics was consistently higher than the rate of female enrolment (Ministry of Education Malaysia, 2013). For example, in 2013 there were 48114 male students enrolled in polytechnic colleges compared to 41389 female students. This difference amounts to 6725 students, and a GPI of 0.86 . However, this gap itself narrowed from 2009-2013. The disparity in favour of male students is even more pronounced in local community colleges, where the GPI has steadily worsened in terms of disparity in favour of males. In 2013, the GPI for enrolment into community colleges in Malaysia was 0.56, with 13738 male students enrolled compared to 21468 female students (Ministry of Education Malaysia, 2013).

However, due to the relatively small size of student enrolment, the gap between male and female students is slightly smaller than compared to the gap of polytechnic students at 6008 students. The relatively small student enrolment size and increasing GPI in polytechnic colleges means that the gender gap among undergraduates in IPTAs cannot be satisfactorily explained by male enrolment in polytechnic institutions and community colleges. The 'missing' number of male students at IPTAs dwarfs the gender gap in these institutions in terms of size, as the difference in number between male and female students in polytechnics and community colleges in 2013 consists of 12733 students, about $14 \%$ of the gender gap in IPTA undergraduate programmes for the same year. Furthermore, this does not address the underlying issue of why boys are choosing to enter polytechnics or community colleges rather than undergraduate programmes, thus lowering their potential future incomes.

\section{Men in Overseas Universities}

Given the dominance of men in the political and economic spheres of Malaysia, it may be posited that male youth are given a privileged position by their families and are sent abroad to receive higher education from more recognised institutions in places such as the UK or the US. Is there a preference for families to send their sons abroad, and can this explain the gender gap? 
According to the UNESCO Institute for Statistics (2016), there are currently 56, 260 Malaysian students studying abroad. Most of these students are in the $\operatorname{UK}(15,583)$ and Australia $(15,357)$, the next closest being the US $(6,486)$. Given these numbers, it is clear that the size of the gender gap in Malaysian public universities is larger than the entire number of Malaysian overseas students put together. This makes it unlikely that the overseas student population can explain the gender gap of Malaysian IPTAs to a significant degree. Furthermore, the overseas student population of Malaysia is far from male dominated. In Australia, the number of male and female students from Malaysia in 2014 was practically equal, with a $49.3 \%$ female and $50.7 \%$ male student population (Australian Government, 2015). In the UK, there is no data available as to what percentage of Malaysian students are male. However, male students studying in the UK from Asia are actually underrepresented, with only $47.21 \%$ of students from Asia studying in the UK being male (HESA, 2016) This would indicate that the Malaysians students studying in the UK are unlikely to be strongly male dominated, and thus overseas students cannot explain the lack of absence of male students in public universities.

\section{Women have Higher Returns for University Education than Men}

One explanation to why women outnumber men in public universities is due to the fact that they receive greater economic incentives for entering higher education. This explanation is grounded in Human Capital theory, an influential economic theory advanced by economists from the Chicago School of Economics such as Gary Becker. It posits that human decisions are based on the economic self-interest of individuals operating within a free market. Hence, enrolment in university education is primarily an investment decision, and women's increasing enrolment in public universities must be due to expanding returns within the labour market. Another Chicago School economist, Francisco Paro, found that 'studies empirically show that the college wage premium for women is higher than the college wage premium for men and has been for at least 40 years', adding that the comparatively high financial returns for women could potentially explain the gender gap (Parro 2012, p.158). However, other examinations of Current Population Survey (CPS) have found that while women's wage returns to higher education have indeed increased, men's returns have increased even more rapidly because jobs for those employed straight out of high school have become increasingly low paid (Diprete and Buchmann 2006, p.2).Overall, it has been found that the human capital theory 'does not provide a particularly convincing explanation' for the gender gap in countries such as the United States and Japan (Vincent-Lancrin 2008, p.282). Does this approach make better sense in the Malaysian context?

Due to the wage gap between men and women in Malaysia, Malaysian women earn $8.4 \%$ less than their male counterparts on average (Lee, 2015). However, it is important to note that this alone does not refute the idea that women can get higher returns for university education; what is important is not the wage gap between men and women but the gap between the earnings of tertiary graduates and non-tertiary graduates. According to the 2012 Salaries \& Wages Survey Report, women with a tertiary degree on average earned more than double the salary of women with just a high school certificate; a premium of 1545 Malaysian Ringgit (RM) on average. However, men with a tertiary degree earned an even larger premium: male tertiary graduates earned an average of RM 3542 as compared to men with a high school certificate who earned an average of RM 1554. This amounts to a premium of RM 1988 on average. Hence, it is clear that men have equal, if not more economic incentives for pursuing higher education and this cannot explain the gender gap in Malaysian public universities.

\section{Girls Perform Better in Secondary School Education}

Girls can outperform boys in secondary school education in two ways: they score better in standardised tests, and they drop out at a lesser rate. There is a positive association of performance in standardised tests, overall marks, and good study habits with university enrolment (Frenette and 
Zeman, 2007). Obviously, a lower dropout rate among girls would increase their chances of making the transition to higher education. These are the two measures of secondary school performance examined here.

The better performance of female students compared to male students has been the most common explanation for the gender gap, both in Malaysia and abroad. "More female applicants had better academic results and performance, which explains the increase in the gender gap," said UKM Professor Othman A. Karim (Kapoor and Au, 2011). The then deputy Vice Chancellor of Universiti Putra Malaysia, Professor Mohd Fauzi Ramlan also insisted that "the female students were just more qualified than the males" (Kapoor and Au, 2011), pointing out that UPM were forced to allocate more residential colleges for women even while vacancies for men still existed. Is there empirical proof that Malaysian women achieve better academic results than Malaysian men?

In 2010, one UNICEF report entitled 'Why are Boys under-performing in Education? Gender Analysis of Four Asia-Pacific Countries' examined national school examination results and educational data from Malaysian Educational Statistics, and found that girls outperformed boys academically in four key subjects (English, Mathematics, Science and Bahasa Malaysia in the years 2005-2007. (Hepworth 2013, p.14) Furthermore, the performance gap between boys and girls in Malaysian government schools began in primary school, and only widened as they progressed to lower secondary and then upper secondary. Another form of standardised tests which we can consider is the Programme for International Student Assessment (PISA) which is a global study carried out by the OECD. Malaysia first participated in the study in 2009. In the 2012 PISA study, 34 OECD countries and 31 partner countries participated the testing of mathematics, reading and science. Overall, there was a small gender gap in favour of boys in science, a large gender gap in favour of boys in mathematics and a large gender gap in favour of girls in reading (OECD 2014, p.66). Malaysia was one of the five countries out of the 65 tested countries in which girls outperformed boys in mathematics, to a statistically significant degree (OECD 2014, p.73). Malaysian girls also outperformed boys in science and reading. The underachievement of Malaysian males in terms of examination results is in accordance to global trends. In the UK, the gender gap between boys and girls in their General Certificate of Secondary Education (GCSE) examinations was the highest in over a decade in 2014, as girls outperformed boys by 8.8 percentage points (Arnett, 2014).

Girls also perform better than boys at staying in school. The drop-out rate for Malaysian school children is very low at primary school levels $(0.8 \%$ in 2014$)$ but rises significantly in secondary school (10\% in 2014) (United Nations Malaysia 2015, p.10). The dropout rate among students transitioning into lower secondary is low for both genders, although female students have a marginally lower dropout rate. However, dropout rates rapidly increase as students enter secondary schooling. Goolamally and Ahmad (2010) found that $9.96 \%$ of boys and $8.02 \%$ of girls dropped out while transitioning into secondary school in the 2005 cohort. They also noted that the rate at which girls dropped out of school from 2006 to 2009 actually decreased, while the rate at which boys dropped out had the opposite trend. This provides evidence for the proposition that girls not only perform better than boys academically while in secondary school, but also drop out at a lower rate. This will undoubtedly have an impact on overall gender parity in universities.

Nevertheless, the gap in secondary school performance in itself does not provide a satisfactory explanation for the enrolment gap in Malaysian universities. It merely shifts the question to why are women systematically performing better than their male counterparts in terms of their examination results, or staying in school at a greater rate. Insofar as we reject naturalistic explanations for gender differences, these factors are a symptom of a deeper, underlying problem. There is research which indicates the size of the gender gap among students is not stagnant, but changes over time, in particular decreasing with regards to career aspirations and degree attainment (Chamberlain, 1988). This suggests that the gender gap is not caused by inherent or genetic dispositions, but caused by wider social phenomena. 


\section{Socialisation}

Socialisation is a broad term used to refer to the lifelong processes in which individuals acquire norms, customs, values and ideologies from their environment, which in turn influences how they interact with society. It suggests that a person's upbringing can heavily impact his or her biological traits, to the extent that different genders may systematically behave differently. This can be caused by interactions during childhood, parental role models, peers or schooling (Sax and Harper 2007, p.4). In the context of the gender gap in Malaysian higher education, it is possible that boys have become socialised to accept unhealthy gender stereotypes, which inhibits their ability to fully partake in academic life and enrol into universities. This socialisation can occur across different aspects of society, such as in parenting, peers and schools.

We can find limited evidence for such socialisation in research done through focus groups surveys of Malaysian undergraduate students. When asked for reasons why boys performed worse than girls in the Malaysian context, participants' felt somewhat strong or strongly in agreement with statements such as 'Boys have to hide their fears', 'Girls are ambitious', 'Girls have a clear vision of the future compared to boys', 'Girls are more disciplined', and 'Girls are hardworking' (Goolamally and Ahmad 2010, p.17) These answers indicate that girl's benefit from positive stereotypes which encourage them to go to university, while conversely boys are given negative stereotypes; implying that masculine attributes include being undisciplined, lazy, lacking in ambition and without vision. This makes it difficult for boys to fully participate in the kinds of activity which will ultimately be essential for flourishing in higher education; for instance, reading is often perceived by boys as a feminine activity (UNICEF 2004, p.63).

Even nominally positive traits associated with boys can be damaging. One of the statements which participants agreed with in the focus group was 'Parents trust a boy's capability to secure a job', which can influence a parent's decision to withdraw their son from school as they are more capable of finding work with competitive wages. This concurs with labour force statistics which find that $33 \%$ of women aged $15-24$ participate in the labour force, as compared to $48 \%$ of men at the same age group (Ministry of Women and Family Development, 2013).

\section{Conclusion}

The paper has found that 13 out of 20 of Malaysian public universities fall under UNESCO's classification of 'far from gender parity', with a GPI higher than 1.5. This includes the University of Malaya, which has significantly higher GPI compared to foreign counterparts in developed nations. We also find that this phenomenon is not replicated in Malaysia's private sector of higher education, where the GPI is much more balanced. The gender gap in terms of public university enrolment extends to every field of study with the exception of engineering, manufacturing and construction; we find in the latter field that Malaysia has succeeded in achieving much closer gender parity compared to other countries in the Asia pacific region and also more developed nations like the US and the UK. Gender parity is much more equal in Malaysian private universities, and among Malaysian overseas educated students. However, there remains a significant gap in Malaysian public universities, as the number of men enrolling into community colleges and polytechnics are insufficient to explain this gap. We find that there is a trend of male underperformance in secondary schooling level which undoubtedly contributes to the gender gap in higher education, as boys attain lower academic achievement and drop out at higher rates overall. This does not suffice as an explanation by itself, without considering how boys and girls are socialised differently from a young age.

Much more research needs to be done in order to produce informed recommendations on how to reduce or mitigate the gender gap at Malaysian public universities. Part of the purpose behind this paper is to open a dialogue among policy makers and academics to focus more attention on the issue of male enrolment in public universities, which has been scarcely discussed despite being acknowledged in the Malaysian Education Blueprint. Based on the evidence reviewed in this paper, we recommend that schools in Malaysia begin to consciously review their role in gender 
socialisation, in terms of 'curriculum materials, teachers' expectations, educational tracking, and peer relations [which] encourage girls and boys to learn gender-related skills and self-concept' (Anderson 2000, p.38). Schools could implement awareness campaigns and work to increase parental involvement in their son's lives; research indicates that parents are usually less involved in their sons' academic lives while daughters hold school discussions with their parents at a higher rate (Carter and Wjtkiewicz, 2000). The gender gap in higher education is one that disproportionately affects males from backgrounds of lower income, as acknowledged in reports from HEPI (Hillman and Robinson, 2016). This is why the gender gap is close to parity in private universities and overseas education. Hence, social policies which target lower income families and communities should have the effect of reducing the gender gap in Malaysian public universities too. This way, we can take steps to address this disparity, while taking care not to roll back the impressive progress that has been made with regard to increasing female participation in all fields of study.

\section{References}

Anderson, M. L. (2000). Thinking about Women: Sociological perspectives on sex and gender (5th edition). Allyn and Bacon: Boston, MA.

Arnett, G. (2014). GCSE Results: Biggest Gap in 11 Years between Boys and Girls A*-C Pass Rate, the Guardian. Available at http://www.theguardian.com/news/datablog/2014/aug/21/gcseresults-2014-biggest-gap-11-boys-and-girls-a-c-pass-rate. [Accessed 15 July 2016].

Australian Government, Department of Education and Training. (2015). International Student Numbers 2014. Available at https://internationaleducation.gov.au/research/ResearchSnapshots/Documents/International\%20Student\%20Numbers\%202014.pdf. [Accessed 15 September 2016].

Birger, J. (2015). Why getting into elite colleges is harder for women. Washington Post, July 30 Available at https://www.washingtonpost.com/posteverything/wp/2015/07/30/achievingperfect-gender-balance-on-campus-isnt-that-important-ending-private-colleges-affirmativeaction-for-men-is/. [Accessed 10 June 2016].

Bobbitt-Zeher, D. (2007). The gender income gap and the role of education. Sociology of Education, $80(1)$, pp. 1-22.

Borzelleca, D. (2012). The Male-Female Ratio in College. Forbes. Available at http://www.forbes. $\mathrm{com} / \mathrm{sites} / \mathrm{ccap} / 2012 / 02 / 16 /$ the-male-female-ratio-in college/\#466c44441525. [Accessed 10 June 2016].

Carter, R. S. and Wojtkiewicz, R. A. (2000). Parental involvement with adolescents' education: Do daughters or sons get more help? Adolescence (Spring), 35(137), pp. 29-44.

Chamberlain, M. K. (1988). Women in Academe: Progress and prospects. New York: Russell Sage Foundation.

CIA. (2016). The World Factbook. Available at https://www.cia.gov/library/publications/the-worldfactbook/fields/2018.html\#download. [Accessed 10 June 2016].

Diprete, T. A. and Buchmann, C. (2006). Gender-specific trends in the value of education and the emerging gender gap in college completion. Demography, 43(1), pp.1-24.

Engineering Stategic Communications. (2015). U of T Engineering Celebrates Record Number of Female First-Year Students. Available at http://news.engineering.utoronto.ca/record-femalefirst-years/. [Accessed 10 June 2016].

Frenette, M. and Zeman, K. (2007). Why Are Most University Students Women? Evidence Based on Academic Performance, Study Habits and Parental Influences, Analytical Studies Branch Research Paper Series, Statistics Canada, Analytical Studies Branch. Available at http:// EconPapers.repec.org/RePEc:stc:stcp3e:2007303e. [Accessed 20 June 2016].

Goh, L. (2015). PM: Malaysia on track to becoming high-income nation by 2020. The Star, September 29. Available at http://www.thestar.com.my/news/nation/2015/09/29/najib-highincome-2020/. [Accessed 20 July 2016]. 
Goolamally, N. and Ahmad, J. (2010). Boys Do Poorly in Schools: The Malaysian Story. Unpublished Manuscript. Available at https://www.researchgate.net/publication/262689050_BOYS_DO_ POORLY_IN_SCHOOLS_THE_MALAYSIAN_STORY. [Accessed 15 July 2016].

Hemel, D. J. (2005). Summers' Comments on Women and Science Draw Ire. The Harvard Crimson. Available at: https://www.thecrimson.com/article/2005/1/14/summers-comments-on-womenand-science/. [Accessed June 20 2016].

Hepworth, F. (2013). Why are Boys Underperforming in Education? Gender Analysis of Four Asia Pacific Countries. United Nations Girls Education Initiative: New York. Available at http://www. unicef.org/eapro/report_why_are_boys_underperforming_FINAL.pdf. [Accessed 20 July 2016].

Higher Education Statistics Agency (HESA). (2016). Students in Higher Education 2014/2015. Available at https://www.hesa.ac.uk/data-and-analysis/publications/students-2014-15. [Accessed 15 August 2016].

Hillman, N. and Robinson, N. (2016.) Boys to Men: The Underachievement of Young Men in Higher Education - And How to Start Tackling It. Higher Education Policy Institute. Available at http:// www.hepi.ac.uk/wp-content/uploads/2016/05/Boys-to-Men.pdf. [Accessed July 20th 2016].

Kapoor, C. and Au, E. (2011). Female Undergrads Outnumber Males: Malaysia, Asia One News, September 8. Available at http://news.asiaone.com/News/AsiaOne\%2BNews/Malaysia/Story/ A1Story20110908-298320.html. [Accessed 15 September 2016].

Khoo, B. T. (2003). Beyond Mahathir: Malaysian politics and its discontents. London: Zed Books.

Lee, P. (2015). Gender-Wage Bias Still Raging, The Star. Available at www.thestar.com.my/news/ nation/2015/01/05/genderwage-bias-still-raging-men-earn-more-doing-the-same-job-onmany-fronts-report-/. [Accessed 10 June 2016].

Mellström, U. (2009). The intersection of gender, race and cultural boundaries, or why is computer science in Malaysia dominated by women? Social Studies of Science, 39(6), pp. 885-907.

Milanovic, B. (2006). Inequality and determinants of earnings in Malaysia, 1984-1997. Asian Economic Journal, 20(2), pp. 191-216.

Ministry of Education Malaysia. (1967). Educational Statistics of Malaysia 1938-1967. Dewan Bahasa dan Pustaka. Available at http://www.fmm.org.my/upload/educational\%20statistics\%20of\%20 malaysia\%201938-1967.pdf. [Accessed July 10 2016].

Ministry of Education Malaysia. (2012). Preliminary Report Malaysia Education Blueprint 2013-2025. Available at www.moe.gov.my/userfiles/file/PPP/Preliminary-Blueprint-Eng.pdf. [Accessed 10 June 2016].

Ministry of Education Malaysia. (2013). Education Statistic: Higher Education Sector. Perpustakaan Negara Malaysia. Available at https://www.mohe.gov.my/en/download/public/ statistik/2013/83-perangkaan-pendidikan-negara-spt-2013/file. [Accessed June 15 2016].

Ministry of Higher Education Malaysia (2010). Statistics of Higher Education Malaysia 2009. Putrajaya: Ministry of Higher Education.

Ministry of Higher Education Malaysia. (2011). Statistics of Higher Education Malaysia 2010. Putrajaya: Ministry of Higher Education.

Ministry of Higher Education Malaysia. (2012). Buku Informasi IPTS 2012 Bertaraf Universiti, Kolej Universiti Dan Kampus Cawangan. Putrajaya: Ministry of Education Malaysia.

Ministry of Higher Education Malaysia. (2012). National Education Statistic: Higher Education Sector. Ministry of Higher Education of Malaysia. Available at https://www.mohe.gov.my/en/ download/public/statistik/2012/84-perangkaan-pendidikan-negara-spt-2012/file. [Accessed June 15 2016].

Ministry of Women, Family and Community Development. (2007). Measuring and Monitoring Gender Equality: Malaysia's Gender Gap Index. Available at http://www.undp.org/content/ dam/malaysia/docs/WomenE/MGGI_report.pdf. [Accessed 10 June 2016].

Ministry of Women and Family Development. (2013). The Progress of Malaysian Women Since Independence. Available at http://www.undp.org/content/dam/malaysia/docs/WomenE/ ProgressOfMalaysianWomen.pdf. [Accessed 10 June 2016]. 
National Student Clearinghouse. (2015). Snapshot Report: Degree Attainment. Available at https:// nscresearchcenter.org/wp-content/uploads/SnapshotReport15-DegreeAttainment.pdf. [Accessed 10 June 2016].

NUS Registrar's Office. (2016). Student and Graduate Statistics National University of Singapore. Available at http://www.nus.edu.sg/registrar/statistics.html. [Accessed July 10 2016].

OECD. (2011). Report on the Gender Initiative: Gender equality in education, employment and entrepreneurship. Paris: OECD.

OECD. (2014). PISA 2012 Results: What Students Know and Can Do. Student Performance in Mathematics, Reading and Science. Paris: OECD Publishing. Available at https://www.oecd. $\mathrm{org} / \mathrm{pisa} /$ keyfindings/pisa-2012-results-volume-I.pdf. [Accessed 15 June 2016].

Onsongo, J. K. (2011). Promoting Gender Equity in Selected Public Universities in Kenya. Addis Ababa, Ethiopia: Organisation for Social Science Research in Eastern and Southern Africa (OSSREA).

Parro, F. (2012). International evidence on the gender gap in education over the past six decades: A puzzle and an answer to it. Journal of Human Capital, 6(2), pp. 150-185.

Pong, S. L. (1999). Gender inequality in educational attainment in Peninsular Malaysia. In C. Heward and S. Bunwaree (Eds.), Gender, Education and Development: Beyond Access to Empowerment. London: Zed Books.

Sax, L. and Harper, C. (2007). Origins of the gender gap: Pre-college and college influences on differences between men and women. Research in Higher Education, 48(6), pp. 669-694.

UCAS. (2015). End of Cycle Report 2015, UCAS Analysis and Research. Available at https://www.ucas. com/sites/default/files/eoc-report-2015-v2.pdf. [Accessed 15 June 2015].

UNESCO. (2012). World Atlas of Gender Equality in Education. Available at http://www.uis.unesco. org/Education/Documents/unesco-world-atlas-gender-education-2012.pdf. [Accessed 10 June 2016].

UNESCO. (2015). A Complex Formula: Girls and Women in Science, Technology, Engineering and Mathematics in Asia. Available at http://unesdoc.unesco.org/images/0024/002457/245717E. pdf. [Accessed 15 June 2016].

UNESCO Institute for Statistics. (2016). Global Flow of Tertiary- Level Students 2014. Available at http://uis.unesco.org/en/uis-student-flow. [Accessed July 20th 2016].

UNICEF. (2004). The State of the World's Children 2004. Available at http://www.unicef.org/sowc04/ files/Chapter5.pdf. [Accessed 15 August 2016].

UNICEF. (2009). Gender Equality in Education: East Asia and Pacific. Available at https://www.unicef. org/eapro/Gender_Snapshot_web.pdf. [Accessed 10 June 2016].

United Nations Malaysia. (2015). Malaysia Millennium Development Goals Report 2015. Available at http://un.org.my/upload/undp_mdg_report_2015.pdf. [Accessed 15 September 2016].

University of Malaya (n.d.). Our History. Available at https://www.um.edu.my/about-um/our-history. [Accessed 2 March 2017].

Vincent-Lancrin, S. (2008). The Reversal of Gender Inequalities in Higher Education: An On-going Trend. Available at https://www.oecd.org/edu/ceri/41939699.pdf. [Accessed 15 June 2016].

Weale, S. (2016). UK's University Gender Gap is a National Scandal, Says Think Tank, The Guardian. Available at: https://www.theguardian.com/education/2016/may/12/university-gender-gapscandal-thinktank-men. [Accessed 15 August 2016].

Weaver-Hightower, M. (2003). The boy turn in research on gender and education. Review of Educational Research, 73(4), pp. 471-498.

World Bank. (2004). Global Monitoring Report 2004: Policies and Actions for Achieving the Millennium Development Goals and Related Outcomes The World Bank pp.42. Available at http://siteresources.worldbank.org/INTGLOBALMONITORING/Resources/GMR_2004.pdf. [Accessed July 15 2016].

World Economic Forum. (2015). The Global Gender Gap Report 2015. Cologne/Geneva: World Economic Forum. 